\title{
A novel association between Aphaenogaster subterranea (Hymenoptera: Formicidae) and the nymphs of Reptalus panzeri (Hemiptera: Cixiidae)
}

\author{
GÁBOR LŐRINCZI
}

Department of Ecology, University of Szeged, Közép fasor 52, H-6726 Szeged, Hungary; e-mail: lorinczig@gmail.com

Key words. Hymenoptera, Formicidae, Aphaenogaster subterranea, Hemiptera, Cixiidae, Reptalus panzeri, ant-hemipteran association, insect-insect relationship, myrmecophily, Fraxinus ornus, ash

\begin{abstract}
The nymphs of the cixiid planthopper, Reptalus panzeri (Löw, 1883), were found cohabiting with the myrmicine ant Aphaenogaster subterranea (Latreille, 1798) in a sub-Mediterranean oak forest in mid-western Hungary. Except for a few cases, nymphs were recorded only in the nests of $A$. subterranea, or were recorded with foragers of this ant from neighbouring colonies. Adult planthoppers were also found in nests of A. subterranea in the emergence period. Neither field nor laboratory studies revealed direct or unambiguous interactions between this ant and the planthopper nymphs that would indicate a trophobiotic relationship, however the fact that nymphs do not try to escape from the ants, which do not attack the nymphs, indicates some kind of mutualistic relationship between them. The main food plant of $R$. panzeri nymphs in this habitat is likely to be the roots of manna ash (Fraxinus ornus).
\end{abstract}

\section{INTRODUCTION}

The association between ants and honeydew-producing hemipterans is well known and discussed extensively in the literature. In these interactions, tending ants harvest energy-rich honeydew and in return provide protection and other services that benefit the hemipterans (reviewed e.g., by Way, 1963; Buckley, 1987; Delabie, 2001).

Ant-attendance of aphids, scale insects, mealybugs (Sternorrhyncha: Aphididae, Coccidae and Pseudococcidae) and treehoppers (Auchenorrhyncha: Membracidae) is the most common and is rare or uncertain in other hemipteran groups (Hölldobler \& Wilson, 1990; Delabie, 2001). Within the Fulgoromorpha, relationships with ants are recorded for at least ten families (China \& Fennah, 1952; Hoch, 1990; Delabie, 2001), including Cixiidae, but these are poorly documented, except for the Tettigometridae (Bourgoin, 1997; Dejean \& Bourgoin, 1998; Dejean et al., 2000; Lehouck et al., 2004).

In ant-cixiid relationships it is mainly the ground-living nymphs that are ant attended (Myers, 1929; Mitjaev, 1967; Thompson et al., 1979; Thompson, 1984) and rarely the adult planthoppers (Holzinger, 2009). In the Central European fauna, the nymphs of species of Reptalus and Pentastiridius are found in association with ants (W.E. Holzinger, pers. com.), however, the species of ant or whether it is frequently associated with these planthoppers is unreported.

In the present paper, I report a close association between the myrmicine ant Aphaenogaster subterranea and the nymphs of the cixiid planthopper Reptalus panzeri. This was first discovered in 2010, when temporal changes in the density and spatial pattern of ant nests were studied from spring to autumn in two subMediterranean woodland habitats (Lörinczi, in prep.) Though detailed records of this association were not made in that study, the nymphs of $R$. panzeri were observed cohabiting with host colonies throughout the season (from early April to late October) and appeared to occur only in the nests of $A$. subterranea. During the study presented here, I attempted to estimate the frequency of occurrence of planthopper nymphs in ant nests and make preliminary observations on the nature of this relationship.

\section{MATERIAL AND METHODS}

\section{Study species}

Aphaenogaster subterranea (Latreille, 1798) is a widely distributed myrmicine ant, which occurs in Central and Southern Europe, Moldova, Southern Ukraine, Crimea, Asia Minor and Caucasus (Kutter, 1977; Czechowski et al., 2002). It is a highly thermophilous species, inhabiting mostly moderately wet and warm deciduous forests and forest edges (Czechowski et al., 2002; Seifert, 2007), but also occurs in pine forests (Garrido et al., 2002; Lörinczi, 2008, 2011; Castracani et al., 2010) and occasionally in dry grasslands (Csősz et al., 2002; Dekoninck et al., 2007). In the area surveyed, A. subterranea is one of the most abundant species of ant and mainly nests under stones, in the soil, leaf litter and occasionally inside and/or under fallen branches (Lőrinczi, 2011). Its colonies are monogynous and range in size from several hundred to several thousand workers (Schmid-Hempel \& Crozier, 1999; Czechowski et al., 2002; Seifert, 2007). A. subterranea is an omnivorous ant and like other species in the genus Aphaenogaster, also uses tools to transfer liquid food back to the colony (Agbogba, 1985; Lörinczi, pers. obs.). Although species of Aphaenogaster are generally classified as opportunists using Andersen's (1995, 1997) functional group scheme (e.g., King et al., 1998; Wike et al., 2010), A. subterranea, contrary to Castracani et al.'s (2010) classification, is categorized as cryptic by Gómez et al. (2003).

Reptalus panzeri (Löw, 1883) is a cixiid planthopper, which occurs in Central and Southern Europe, England, Asia Minor and Caucasus, where it inhabits xerothermous habitats, especially sunny hillsides or plateaus up to $500 \mathrm{~m}$ (Holzinger et al., 
2003). It is a polyphagous species with a wide variety of host plants, including trees, shrubs and also herbaceous plants (Nickel \& Remane, 2002; Nickel, 2003; Jović et al., 2009; Bertin et al., 2010). Similar to other members of the family, the wax-tailed nymphs live underground, feeding on the roots of their host plants (see Figs 2-3). It has one generation per year and overwinters in the nymphal stage. Imagoes are active from mid-June to the beginning of August (Nickel \& Remane, 2002; Holzinger et al., 2003; Jović et al., 2009). R. panzeri is of great economic importance because it is a potential vector of stolbur phytoplasma, a prokaryotic, phloem-restricted plant pathogen, which causes diseases in a number of economically important plants (Palermo et al., 2004; Riedle-Bauer et al., 2006; Jović et al., 2007, 2009).

\section{Study area}

This study was carried out in the oak forest on the south-facing slope of Péter Hill (Péter-hegy) $\left(46^{\circ} 58^{\prime} 33.54^{\prime \prime} \mathrm{N}\right.$, $17^{\circ} 53^{\prime} 34.62^{\prime \prime} \mathrm{E}$, altitude $207 \mathrm{~m}$, dip angle $15-20^{\circ}$ ), which is located in the middle of the Balaton Uplands, in mid-western Hungary. The climate in this region is mild, with a mean annual temperature of $10-15^{\circ} \mathrm{C}$ and mean annual precipitation of 650-700 $\mathrm{mm}$ (Füleky et al., 2007). The type of forest in this area is a mosaic of karst shrub (Cotino-Quercetum pubescentis) and downy oak forest (Vicio sparsiflorae-Quercetum pubescentis) with downy oak (Quercus pubescens) and manna ash (Fraxinus ornus) being the dominant tree species (Borhidi, 2003). Detailed information about the vegetation in this area can be found in Debreczy (1973).

\section{Field work}

Ant nests were mapped and excavated in $25(5 \times 5)$ randomly placed plots of $3 \times 3 \mathrm{~m}^{2}$ on five occasions between the end of May and beginning of September 2011 (see Table 2). Every time an ant's nest was found the following parameters were recorded: (1) the type of nesting site (i.e., under a stone, in the soil, leaf-litter or in fallen branches); (2) the estimated size of the colony (small, medium, large) on the basis of the number of workers/brood and the extent of the nest; (3) the presence, number, estimated size (small, medium, large) and exact location of individual planthopper nymphs inside the ant's nest; (4) all the species of shrubs and trees close to the nest the roots of which could be present in the nests.

During nest mapping, I ignored such specific nesting sites as small twigs, acorns, galls or empty snail shells, where planthopper nymphs were unlikely to occur, so the nests of twig- nester/cavity-nester ant species (e.g., Temnothorax spp.) were undoubtedly under-represented in this study.

Planthoppers could be determined to species level only after adult males were found, since reliable identification of Reptalus species is based on the morphology of the male genitalia (Holzinger et al., 2003), however, it is now possible using DNAbased assays to identify nymphs and adult females (Bertin et al., 2010). Planthopper nymphs were kindly identified to family level and adults to species level by György Györffy (Department of Ecology, University of Szeged). Voucher specimens of ants were identified using the keys of Seifert (2007).

\section{Laboratory work}

Since detailed observations could not be carried out in the field as the ants were disturbed by opening their nest, a laboratory study was undertaken to determine the behavioural interactions between the two species. On three occasions fragments of colonies of A. subterranea and planthopper nymphs from nests were separately transferred to the laboratory. Within a few hours of collecting in the field nymphs were placed in Petri dishes with rootlets and nest material, and then workers of $A$. subterranea were added and the reactions of both species to one another was recorded.

\section{RESULTS}

Altogether, a total of 147 nests of 9 ant species were found during nest mapping. The most frequent species was $A$. subterranea, whose nests made up more than $50 \%$ of all nests found and were found in all the plots except one (Table 1). Like in nearly all the other species most of the nests of $A$. subterranea were found under stones.

Overall, a total of 110 planthopper nymphs were located in ant nests, $106(96 \%)$ of which occurred in the nests of A. subterranea. Nymphs were only recorded in three cases with colonies of other species, two cases in the nests of Prenolepis nitens and one in a satellite nest of Lasius brunneus. It may be worthy of note, however, that within one-meter of the nests of these two species of ants there were nests of $A$. subterranea.

The mean number of nymphs in the $31(40 \%)$ nests of A. subterranea was $3.42( \pm 2.84 \mathrm{SD})$, the minimum number was 1 and the maximum 12 . The ratios of nests with and without nymphs varied from $1: 0.84$ to $1: 4$ at the different times sampled (Table 2). Dead nymphs were

TABLE 1. List of the species of ants, their relative abundance and incidence and frequency of the types of nesting sites used by these ants. Relative abundance is the ratio of the number of nests of each species to the total number of nests found and relative incidence the ratio of the number of plots in which nests of each species occurred to the total number of plots.

\begin{tabular}{|c|c|c|c|c|c|c|}
\hline \multirow[b]{2}{*}{ Species } & \multirow{2}{*}{$\begin{array}{c}\text { Relative } \\
\text { abundance }\end{array}$} & \multirow{2}{*}{$\begin{array}{l}\text { Relative } \\
\text { incidence }\end{array}$} & \multicolumn{4}{|c|}{ Type of nesting site } \\
\hline & & & $\begin{array}{l}\text { under } \\
\text { stones }\end{array}$ & soil & leaf-litter & $\begin{array}{c}\text { fallen } \\
\text { branches }\end{array}$ \\
\hline Aphaenogaster subterranea (Latreille, 1798) & 0.51 & 0.96 & 0.79 & 0.11 & 0.05 & 0.05 \\
\hline Prenolepis nitens (Mayr, 1853) & 0.27 & 0.72 & 0.95 & - & 0.025 & 0.025 \\
\hline Lasius emarginatus (Olivier, 1792) & 0.07 & 0.24 & 0.59 & 0.18 & 0.23 & - \\
\hline Lasius brunneus (Latreille, 1798) & 0.05 & 0.20 & 0.625 & 0.375 & - & - \\
\hline Lasius citrinus Emery, 1922 & 0.04 & 0.16 & 0.83 & 0.17 & - & - \\
\hline Ponera coarctata (Latreille, 1802) & 0.03 & 0.16 & 1 & - & - & - \\
\hline Myrmecina graminicola (Latreille, 1802) & 0.01 & 0.04 & 1 & - & - & - \\
\hline Temnothorax crassispinus (Karavajev, 1926) & 0.01 & 0.04 & - & - & - & 1 \\
\hline Temnothorax unifasciatus (Latreille, 1798) & 0.01 & 0.04 & - & - & - & 1 \\
\hline
\end{tabular}




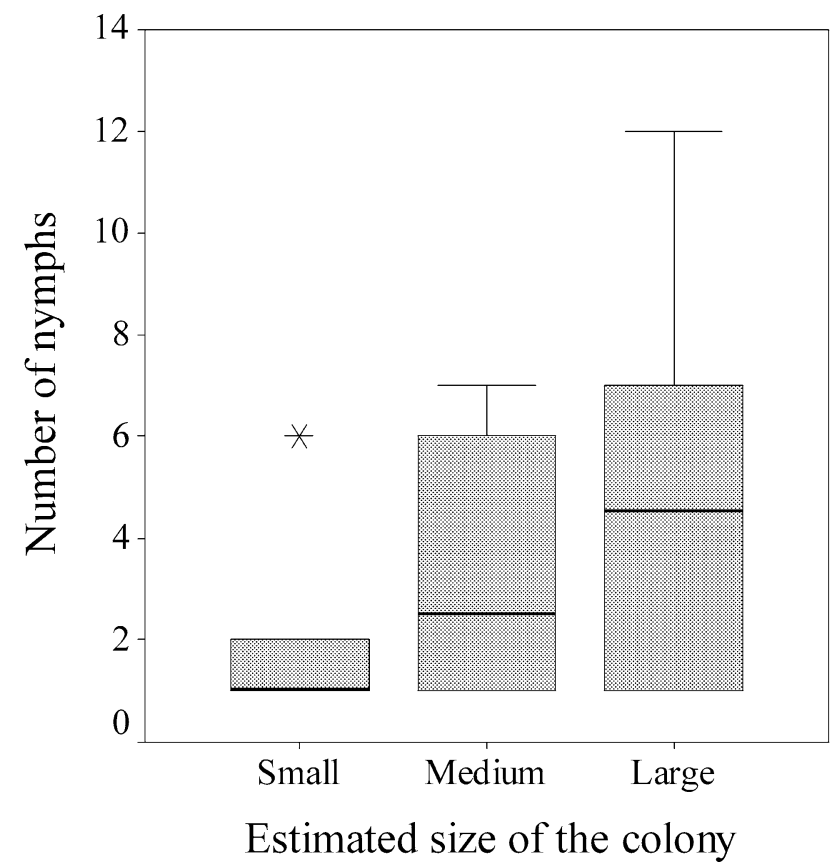

Fig. 1. The number of Reptalus panzeri nymphs in nests of colonies of Aphaenogaster subterranea of different sizes. The differences are not significant (Kruskal-Wallis test, $\mathrm{p}=0.18$ ).

found in three other A. subterranea nests and two nests contained only the characteristic waxy material produced by nymphs. The numbers of planthopper nymphs found in nests of colonies of $A$. subterranea of different sizes did not differ significantly (Kruskal-Wallis test, $\mathrm{p}=0.18$ ) (Fig. 1). Groups of nymphs usually consisted of individuals of different instars, although a greater proportion was made up of young instars in the samples collected after than, before the middle of July (Table 2).

Nymphs were found on six occasions outside ant nests, either singly or in pairs, never in groups, almost always accompanied by foragers of $A$. subterranea from neighbouring colonies even in the one of two cases when a nymph was found in a nest of $P$. nitens.

Inside the nests of $A$. subterranea, nymphs or groups of nymphs were either covered or not covered in waxy threads and located among groups of ant pupae, or, in the case of the nests under stones, on the undersurface of the stones (Fig. 3). Only in a few cases were nymphs found on roots in ant nests (Fig. 2). In the case of the largest group of 12 nymphs found during this study they were found aggregated aboveground in the leaf-litter, covered in waxy threads, directly beneath a fallen branch inhabited by a large colony of $A$. subterranea.

Most of the nests of $A$. subterranea with planthopper nymphs $(65 \%)$ were found among roots, or close to manna ash (Fraxinus ornus) trees. This was also the host plant of the nymphs that were observed feeding on roots inside ant nests. In the remaining cases, the identity of the food plant could not be determined, however, it is likely that downy oak (Quercus pubescens), and perhaps European cornel (Cornus mas) and field maple (Acer campestre) are also host plants of the nymphs of $R$. panzeri.

Independently of the nest-mapping study, adult planthoppers were also observed on three occasions in the nests of $A$. subterranea at the end of June / beginning of July. Two of them were newly emerged and lightly pigmented tenerals, while the third was a fully developed adult that was ready to fly.

In the laboratory, no direct physical contact between ants and planthopper nymphs was recorded. Although ant workers did not attack the nymphs and nymphs did not attempt to escape (e.g., by jumping), but stayed still, they virtually ignored each other in most cases. There was only one case when one of the nymphs slightly raised and shook its abdomen in the presence of an ant worker, and emitted a droplet of honeydew, but the ant did not respond.

\section{DISCUSSION}

Within the Fulgoromorpha, ant-planthopper associations are documented mainly for the Tettigometridae (Bourgoin, 1997; Dejean \& Bourgoin, 1998; Dejean et al., 2000; Lehouck et al., 2004), which account for almost three-quarters of the records of ant attendance in this suborder. Previous studies on ant-cixiid relationships are rare, and most of them report only observations that might indicate the existence of possible associations (Myers, 1929; Thompson et al., 1979; Neece, 1980).

One of the reasons that so few ant-cixiid interactions are reported may be that cixiid planthoppers have characteristics not really favouring associations with ants, contrary to, e. g., tettigometrid species, which possess several morphological (e.g., no jumping apparatus, no wax plates, etc.) and behavioural adaptations (e.g., sessile behaviour, subsociality, etc.) to ant-attendance (Bourgoin, 1997).

TABLE 2. Presence-absence, total number and estimated sizes of Reptalus panzeri nymphs in the nests of Aphaenogaster subterranea on five dates during the course of a year.

\begin{tabular}{|c|c|c|c|c|c|}
\hline \multirow{2}{*}{ Sampled on } & \multicolumn{2}{|c|}{ Number of nests } & \multicolumn{3}{|c|}{ Number and sizes of nymphs found in nests } \\
\hline & with nymphs & without nymphs & small & medium & large \\
\hline 30 May & 8 & 8 & - & 7 & 21 \\
\hline 10 June & 4 & 6 & 1 & - & 27 \\
\hline 19 July & 3 & 12 & 3 & 1 & - \\
\hline 1 August & 10 & 11 & 27 & 5 & - \\
\hline 12 September & 7 & 6 & 2 & 12 & - \\
\hline Total & 32 & 43 & 33 & 25 & 48 \\
\hline
\end{tabular}




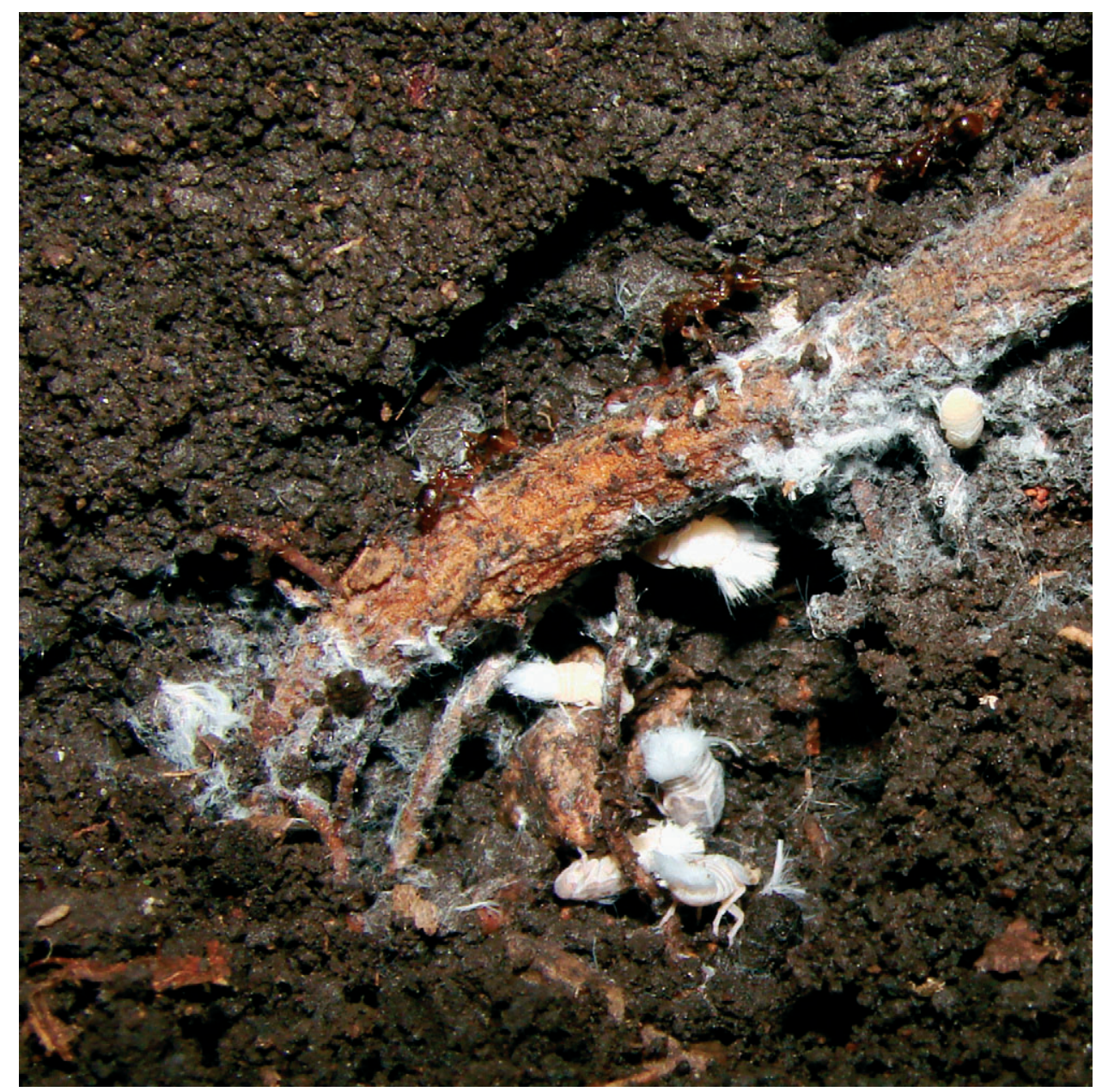

Fig. 2. A group of Reptalus panzeri nymphs on wax covered roots with workers of Aphaenogaster subterranea.

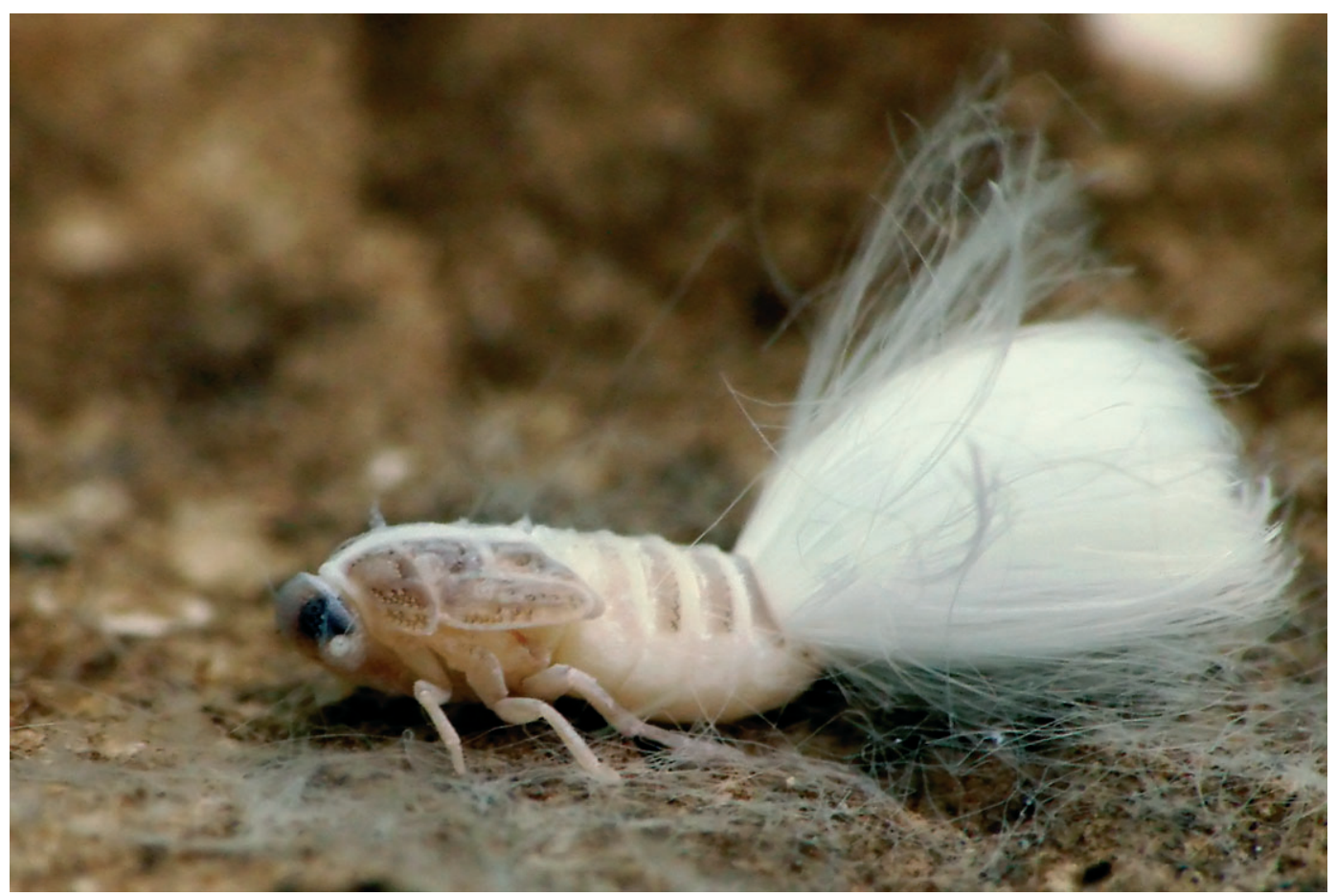

Fig. 3. A late instar nymph of Reptalus panzeri on the undersurface of an overturned stone that previously covered a nest of Aphaenogaster subterranea. 
Nevertheless, durable ant-planthopper interactions may exist not only when hoppers are either sessile (nonjumping) or subsocial, but also when they are just unable to escape or forced to be gregarious (Bourgoin, 1997). Examples of the latter can be seen in the case of some epigeic delphacid species, which are found under ant shelters (Dejean et al., 1996) and of cixiid nymphs, some of which occur underground in ant nests (e.g., Mitjaev, 1967; Thompson, 1984). A special case is represented by some fulgoroid planthoppers with troglomorphies, i.e., morphological adaptations to subterranean or cavernicolous life, e.g., reduced eyes, wings and body pigmentation, presence of sensory hairs, etc. (China \& Fennah, 1952; Hoch, 1990; Fletcher \& Moir, 2009), which may have been facilitated by their associations with ants (Hoch et al., 2006).

According to Bourgoin (1997), four main types of antattendance can be distinguished within the Fulgoromorpha: (1) opportunistic or occasional attendance by ants that collect the honeydew casually dispersed by the planthoppers on the substrate; (2) underground attendance in ant nests; (3) aboveground attendance under natural shelters or shelters built by ants; (4) regular attendance by ants that antennate the planthoppers and collect honeydew directly from their anal openings. Similar to other reported cases of ant-cixiid associations, the relationship between $A$. subterranea and the nymphs of $R$. panzeri is a case of the second type of interaction, which is based only on cohabitation, without further evidence of trophobiotic interactions. At present, there is only one study that reports an advanced type of trophobiosis between ants and cixiids, involving, however, adult planthoppers, not subterranean nymphs (Holzinger, 2009).

It is suggested that the association reported here is facultative for A. subterranea as more nests were recorded without than with planthopper nymphs, although the exact ratio seems to be nearly $1: 1$ if the nests with only dead nymphs or traces of nymphs are also included. On the other hand, the association of $R$. panzeri with its ant partner appears to be obligatory as (1) most of the nymphs were found inside ant nests and (2) those nymphs found outside nests were almost in all cases accompanied by workers of $A$. subterranea from neighbouring colonies. Furthermore, although there is no direct evidence that planthoppers overwinter in ant nests, my previous and present results suggest that nymphs cohabit with ants from their first instar to adult emergence (see Table 2). The relationship also seems to be monospecific as the nymphs of $R$. panzeri were almost always exclusively associated with colonies or workers of $A$. subterranea. These are in contrast to many previous studies showing that the association of myrmecophilous leafhoppers and planthoppers with ants is mainly facultative, independently of how advanced the interactions are between them (Steiner et al., 2004; Pfeiffer \& Linsenmair, 2007; Maravalhas \& Morais, 2009). Even when they are obligatory ant-attended, hoppers associate most often with more than one ant species (Dejean et al.,
2000; Moya-Raygoza \& Nault 2000; Lehouck et al., 2004).

One can argue, nevertheless, that the almost exclusive preference of $R$. panzeri for nests of $A$. subterranea may be largely a result of the fact that this species of ant was the most abundant in this habitat during this study. However, according to previous studies carried out over a longer time-scale, $P$. nitens is a much more abundant species, which tends to expand its polydomous nest system in early spring and late autumn (Lörinczi, in prep.). Yet, contrary to this, in neither of these crucial periods were the nymphs of $R$. panzeri found in nests of $P$. nitens. Furthermore, the nymphs of $R$. panzeri have also been found in one particular mixed coniferous-deciduous forest in cohabitation with A. subterranea (Lörinczi, pers. obs.), suggesting that a close association between them is not limited to one habitat. Within the Cixiidae, a similar type of close relationship is reported between the formicine ant Nylanderia (= Paratrechina) arenivaga and the nymphs of Oecleus borealis in North-America (Thompson, 1984). In this case it is suggested that Oecleus nymphs might benefit from being able to feed on the roots of their host plant that are exposed by the excavations of the ants inside their nests and the ant from feeding on honeydew, although no trophobiotic interactions were observed.

Although no collecting of honeydew or direct physical contacts between the nymphs and ants were observed in this study, it is likely that there is some kind of mutualistic relationship between $A$. subterranea and $R$. panzeri, as (1) ant workers did not show predatory or agonistic behaviour towards planthopper nymphs; (2) nymphs, even though saltatory, did not attempt to escape from ants; (3) nymphs located outside of the nests of $A$. subterranea were generally visited by the foragers of this species, even when they were in the nests of other species of ant. Further investigations are needed, though, to prove that nymphs are not just tolerated inquilines in the nests of A. subterranea, benefiting from better accessibility to the roots of their host plants, but are trophobiotic partners of ants, as observed in many cases of ant-hemipteran relationships (see Delabie, 2001, and references therein). More detailed studies on the Aphaenogaster-Reptalus association may not only provide insights into the true nature of this particular relationship, but may also, more generally, offer a better understanding of ant-cixiid associations.

ACKNOWLEDGEMENTS. I am grateful to Gy. Györffy (Department of Ecology, University of Szeged) who kindly identified the planthoppers. I also wish to thank L. Gallé, I. Maák and J. Márton for their valuable comments on the manuscript.

\section{REFERENCES}

Agbogba C. 1985: Observations sur la récolte de substances liquids et de sucs animaux chez deux espèces d'Aphaenogaster: A. senilis et A. subterranea (Hym. Formicidae). Insectes Soc. 32: $427-434$.

ANDERSEn A.N. 1995: A classification of Australian ant communities based on functional groups which parallel plant life- 
forms in relation to stress and disturbance. J. Biogeogr. 22: $15-29$.

ANDERSEN A.N. 1997: Functional groups and patterns of organisation in North American ant communities: A comparison with Australia. J. Biogeogr. 24: 433-460.

Bertin S., Picciau L., Ács Z., Alma A. \& Bosco D. 2010: Molecular differentiation of four Reptalus species (Hemiptera: Cixiidae). Bull. Entomol. Res. 100: 551-558.

Borhidi A. 2003: Magyarország növénytársulásai. (Plant Associations of Hungary.) Akadémiai Kiadó, Budapest, 610 pp. [in Hungarian].

BouRGOIN T. 1997: Habitat and ant-attendance in Hemiptera: a phylogenetic test with emphasis on trophobiosis in Fulgoromorpha. In Grandcolas P. (ed.): The Origin of Biodiversity in Insects: Phylogenetic Tests of Evolutionary Scenarios. Mémoires du Muséum National d'Historie Naturelle 173, Paris, pp. 109-124.

BucKLEY R.C. 1987: Interactions involving plants, Homoptera, and ants. Annu. Rev. Ecol. Syst. 8: 111-135.

Castracani C., Grasso D.A., Fanfani A. \& Mori A. 2010: The ant fauna of Castelporziano Presidential Reserve (Rome, Italy) as a model for the analysis of ant community structure in relation to environmental variation in Mediterranean ecosystems. J. Insect Conserv. 14: 585-594.

China W.E. \& Fennah R.G. 1952: A remarkable new genus and species of Fulgoroidea (Homoptera) representing a new family. Ann. Mag. Nat. Hist. 12: 189-199.

Csősz S., Markó B., Kiss K., Tartally A. \& Gallé L. 2002: The ant fauna of the Fertö-Hanság National Park (Hymenoptera: Formicoidea). In: The Fauna of the Fertö-Hanság National Park. Hungarian Natural History Museum, Budapest, pp. 617-629.

Czechowski W., Radchenko A. \& Czechowska W. 2002: The Ants (Hymenoptera, Formicidae) of Poland. MIZ PAS, Warszawa, $200 \mathrm{pp}$

Debreczy Zs. 1973: The coenological investigations of Péterhegy (mountain) and its environs in the Balaton Upland. Veszprém Megyei Múzeumok Közleményei 12: 191-220 [in Hungarian with English abstr.].

Dejean A. \& Bourgoin T. 1998: Relationships between ants (Hymenoptera: Formicidae) and Euphyonarthex phyllostoma (Hemiptera: Tettigometridae). Sociobiology 32: 91-100.

Dejean A., Ngnegueu P.R. \& Bourgoin T. 1996: Trophobiosis between ants and Peregrinus maidis (Hemiptera, Fulgoromorpha, Delphacidae). Sociobiology 28: 111-120.

Dejean A., Bourgoin T. \& Orivel J. 2000: Ant defence of Euphyonarthex phyllostoma (Homoptera: Tettigometridae) during trophobiotic associations. Biotropica 32: 112-119.

Dekoninck W., De Koninck H., Baugnée J.-Y. \& Maelfait J.-P. 2007: Ant biodiversity conservation in Belgian calcareous grasslands: active management is vital. Belg. J. Zool. 137: 137-146.

DelabiE J.H.C. 2001: Trophobiosis between Formicidae and Hemiptera (Sternorrhyncha and Auchenorrhyncha): an overview. Neotrop. Entomol. 30: 501-516.

Fletcher M.J. \& MoIR M.L. 2009: Budginmaya eulae gen. et sp. nov., a myrmecophilous planthopper (Hemiptera: Fulgoromorpha: Flatidae) from Western Australia. Austral. J. Entomol. 48: 36-39.

Füleky Gy., JaKab S., Fehér O., Madarász B. \& Kertész Á. 2007: Hungary and the Carpathian Basin. In Arnalds Ó., Bartoli F., Buurman P., Oskarsson H., Stoops G. \& GarciaRodeja E. (eds): Soils of Volcanic Regions in Europe. Springer, Berlin, pp. 29-42.

Garrido J.L., Rey P.J., Cerdá X. \& Herrera C.M. 2002: Geographical variation in diaspore traits of an ant dispersed plant
(Helleborus foetidus): are ant community composition and diaspore traits correlated? J. Ecol. 90: 446-455.

Gómez C., Casellas D., Oliveras J. \& Bas J.M. 2003: Structure of ground-foraging ant assemblages in relation to land-use change in the northwestern Mediterranean region. Biodivers. Conserv. 12: 2135-2146.

Hосн H. 1990: Cavernicolous Meenoplidae of the genus Phaconeura (Homoptera: Fulgoroidea) from Australia. Bishop Mus. Occas. Pap. 30: 188-203.

Hoch H., Asche M., Burwell C., Monteith G. \& Wessel A. 2006: Morphological alteration in response to endogeic habitat and ant association in two new planthopper species from New Caledonia (Hemiptera: Auchenorrhyncha: Fulgoromorpha: Delphacidae). J. Nat. Hist. 40: 1867-1886.

HOLZINGER W.E. 2009: A novel trophobiosis between ants (Hymenoptera: Formicidae) and a palm-feeding planthopper (Hemiptera: Cixiidae). Afr. Entomol. 17: 115-118.

Holzinger W.E., Kammerlander I. \& Nickel H. 2003: The Auchenorrhyncha of Central Europe - Die Zikaden Mitteleuropas. Vol. 1: Fulgoromoropha, Cicadomorpha excl. Cicadellidae. Brill, Leiden, $673 \mathrm{pp}$.

Hölldobler B. \& Wilson E.O. 1990: The Ants. Belknap Press of Harvard University, Cambridge, MA, 732 pp.

Jović J., Cvrković T., Mitrović M., Krnjajić S., Redinbaugh M. G., Pratt R.C., Gingery R.E., Hogenhout S.A. \& Toševski I. 2007: Roles of stolbur phytoplasma and Reptalus panzeri (Cixiinae, Auchenorrhyncha) in the epidemiology of Maize redness in Serbia. Eur. J. Plant Pathol. 118: 85-89.

Jović J., Cvrković T., Mitrović M., Krnjajić S., Petrović A., Redinbaugh M.G., Pratt R.C., Hogenhout S.A. \& Toševski I. 2009: Stolbur phytoplasma transmission to maize by Reptalus panzeri and the disease cycle of Maize Redness in Serbia. Phytopathology 99: 1053-1061.

King J.R., Andersen A.N. \& CutTer A.D. 1998: Ants as bioindicators of habitat disturbance: validation of the functional group model for Australia's humid tropics. Biodivers. Conserv. 7: $1627-1638$.

KutTer H. 1977: Hymenoptera, Formicidae. In: Insecta Helvetica, Fauna Bd. 6. Schweizerische Entomologische Gesellschaft, Zürich, 298 pp.

Lehouck V.S., Bonte D.B., Dekoninck W. \& Maelfait J.-P.E. 2004: Trophobiotic relationships between ants (Hymenoptera: Formicidae) and Tettigometridae (Hemiptera: Fulgoromorpha) in the grey dunes of Belgium. Eur. J. Entomol. 101: 547-553.

LÖRINCZI G. 2008: Composition and diversity of ant communities (Hymenoptera: Formicidae) in sub-Mediterranean habitats of Litér. Folia Mus. Hist.-Nat. Bakon. 25: 89-99 [in Hungarian with English abstr.].

LöRINCZI G. 2011: Density and spatial pattern of nests in subMediterranean ground-dwelling ant communities (Hymenoptera: Formicidae). Commun. Ecol. 12: 51-57.

Maravalhas J. \& Morais H.C. 2009: Association between ants and a leafhopper (Cicadellidae: Idiocerinae) in the central brazilian cerrado. Fla Entomol. 92: 563-568.

MitjaEv I.D. 1967: New and poorly known species of Homoptera, Auchenorrhyncha from East Kazakhstan. Entomol. Obozr. 46: 712-723 [in Russian].

Moya-Raygoza G. \& Nault L.R. 2000: Obligatory mutualism between Dalbulus quinquenotatus (Homoptera: Cicadellidae) and attendant ants. Ann. Entomol. Soc. Am. 93: 929-940.

MYERS J.G. 1929: Observations on the biology of two remarkable cixiid planthoppers (Homoptera) from Cuba. Psyche 36: 283-292. 
Neece K.C. 1980: A Faunistic Survey of the Organisms Associated with Ant Colonies of West Texas (Especially Solenopsis spp.). M.S. thesis, Texas Tech. University, $99 \mathrm{pp}$.

Nickel H. 2003: The Leafhoppers and Planthoppers of Germany (Hemiptera, Auchenorrhyncha): Patterns and Strategies in a Highly Diverse Group of Phytophagous Insects. Pensoft, Sofia-Moscow, $460 \mathrm{pp}$.

Nickel H. \& Remane R. 2002: Artenliste der Zikaden Deutschlands, mit Angabe von Nährpflanzen, Nahrungsbreite, Lebenszyklus, Areal und Gefährdung (Hemiptera, Fulgoromorpha et Cicadomorpha). Beitr. Zikadenk. 5: 27-64.

Palermo S., Elekes M., Botti S., Ember I., Alma A., Orosz A., Bertaccini A. \& Kölber M. 2004: Presence of stolbur phytoplasma in Cixiidae in Hungarian vineyards. Vitis 43: 201-203.

Pfeiffer M. \& Linsenmair K.E. 2007: Trophobiosis in a tropical rainforest on Borneo: Giant ants Camponotus gigas (Hymenoptera: Formicidae) herd wax cicada Bythopsyrna circulata (Auchenorrhyncha: Flatidae). Asian Myrmecol. 1: 105-119.

Riedle-Bauer M., Tiefenbrunner W., Otreba J., Hanak K., Schildberger B. \& Regner F. 2006: Epidemiological observations on bois noir in Austrian vineyards. Mitt. Klosterneuburg 56: 166-170.
Schmid-Hempel P. \& Crozier R.H. 1999: Polyandry versus polygyny versus parasites. Philos. Trans. R. Soc. (B) 354: 507-515.

SeIFert B. 2007: Die Ameisen Mittel- und Nordeuropas. Lutra \& Vertriebsgesellschaft, Görlitz, 368 pp.

Steiner F.M., Schlick-Steiner B.C., Holzinger W., Komposch C., Pazoutova S., Sanetra M. \& Christian E. 2004: A novel relationship between ants and a leafhopper (Hymenoptera: Formicidae; Hemiptera: Cicadellidae). Eur. J. Entomol. 101: 689-692.

Thompson C.R. 1984: Association of Paratrechina arenivaga (Hymenoptera: Formicidae), with nymphs of Oecleus borealis (Homoptera: Cixiidae). J.N.Y. Entomol. Soc. 92: 35-41.

Thompson C.R., Nickerson J.C. \& Mead F.W. 1979: Nymphal habitat of Oliarus vicarius (Homoptera: Cixiidae), and possible association with Aphaenogaster and Paratrechina (Hymenoptera: Formicidae). Psyche 86: 321-326.

WAY M.J. 1963: Mutualism between ants and honeydewproducing Homoptera. Annu. Rev. Entomol. 8: 307-344.

Wike L.D., Martin F.D., Paller M.H. \& Nelson E.A. 2010: Impact of forest seral stage on use of ant communities for rapid assessment of terrestrial ecosystem health. J. Insect Sci. 10(77): 1-16.

Received February 2, 2012; revised and accepted April 27, 2012 